\title{
The Liability of the Producer of False Halal Products under Product Liability Law
}

\author{
Naemah Amin ${ }^{1} \&$ Norazlina Abdul Aziz ${ }^{1}$ \\ ${ }^{1}$ Ahmad Ibrahim Kulliayyah of Laws, International Islamic University Malaysia, Kuala Lumpur, Malaysia \\ Correspondence: Naemah Amin, Department of Civil Law, Ahmad Ibrahim Kulliyyah of Laws, IIUM, Malaysia. \\ E-mail: naemah@iium.edu.my
}

Received: February 10, 2015

Accepted: March 13, 2015 Online Published: May 15, 2015

doi:10.5539/ass.v11n15p295

URL: http://dx.doi.org/10.5539/ass.v11n15p295

\begin{abstract}
The ultimate physical outcomes of compliance with halal requirements in Islamic production are high quality and safe products. The producers or suppliers, who claim that their products are halal but in actual fact are not halal, are subject to criminal sanctions under relevant laws in Malaysia. The question arises as to whether the producers of non-halal products can also be liable for physical or emotional injury caused to the victims of such products. This paper aims to explore the potential liability of the producer and supplier of false halal products under the product liability law which generally concerns with providing protection to consumers against unsafe products. The paper specifically examines the provisions of strict liability for defective products under Part X of Consumer Protection Act 1999 (CPA). The main questions to be answered are whether non-halal products can be considered as 'defective' and what kind of injury can be recovered by the victims. The findings of this study provide insights to producers and suppliers on the civil liability for supplying supposedly halal products and recognition of consumer right of redress for injury caused by non-halal products.
\end{abstract}

Keywords: False halal products, producer, product liability, consumers

\section{Introduction}

In the midst of remarkable development of the halal industry in Malaysia, the issue of halal certificate forgery, misuse of halal logo and other forms of false and misleading halal claims continue to haunt halal consumers. The legal solution to the problem has always been criminal sanctions under various statutes (Part 11 of the Consumer Protection Act 1999; Trade Description (Certification and Marking of Halal) Order 2011; Shariah State Enactments). Thus most studies on abuse of halal logo have been focusing on the adequacy of the existing law and the effectiveness of its enforcement in punishing the offender (Afifi \& Alisa, 2014). Without denying the noble deterrent function of criminal law it however does not provide for the victim of non-halal products to be compensated by the wrongdoers. The question thus arises as to whether the producers of non-halal products labelled as halal can also be liable for physical or emotional injury caused to the victims of such products. This issue and other aspects of civil liability of producers and suppliers of false halal products have never been properly studied. Thus, adopting a content analysis method, this paper aims to explore the potential liability of the producer and supplier of non-halal products under the product liability law which generally concerns itself with providing protection to consumers against unsafe products. The paper specifically examines the provisions of strict liability for defective products under Part X of the Consumer Protection Act 1999 (CPA).

It first provides an overview of the concept of halal and its significance in the life of Muslim consumers. This background knowledge is very important in understanding the potential harm that may be caused to them due to the supply of false halal products. The discussion subsequently highlights the potential civil liability of the producer and other parties in the chain of distribution for breach of warranty or guarantees under the law of sale and for breach of duty of care under the tort of negligence. The rest of the paper is devoted to the discussion on the requirements to succeed in establishing a case under the strict product liability law. The product must be proved to be defective before liability can be imposed on the producers. The discussion on the concept of defectiveness aims at discovering the possibility of non-halal product to fall under the purview of defective product. The paper further identifies parties that can be held responsible for producing and supplying false halal products. The purpose is to uncover the scope of liability of all parties involved along the supply chain. Finally, this paper discusses the nature of injury that may be caused to Muslim consumers supplied with non-halal 
products. The conclusion sums up the theoretical and practical challenges for a successful product liability claim grounded on false halal products and thus limit the producer's legal exposure.

\section{The Concept of Halal and Its Importance for Muslims}

The term Halal is from the Arabic word halla which literally means loosening a knot, lawful, free, that which is allowed, permitted, or permissible, legal, licit, legitimate (Yusoff, 2004). From the meaning of "to loose a knot" it is used idiomatically to mean "to make something lawful or permissible" which is the opposite of harrama which means "to forbid", "prohibit" or "disallow". The Arabic definition has also elaborated the word halal as a term describing any object or an action which is permissible to use or engage in (Khattak et al., 2011; Qureshi et al., 2012). In other words, halal is not only confined to food as it has always been misunderstood but it encompasses every product and service that consumers consume or use in their everyday life. Undeniably however, halal food is the central heart of halal concept since food is the main concern of human consumption. As such, most verses of Al-Quran on halal relate to food (Al-An'am: 145; Al-Baqarah: 172). In the context of food, the term halal is always accompanied with the word thoyyiban which generally means wholesome. In many verses the term halalan tayyeban is repeated in the Quran to denote the concept of food in Islam which does not only refer to halal but also good or wholesome food;

"So eat of the lawful and good (clean) food [halalan tayyeban] which Allah has provided for you, and thank the bounty of your Lord if it is Him that you serve or worship" (Surah An-Nahl (16): 14)

"...He allows to be lawful for them things (that are) clean [At-tayyebaat] and forbids for them things unclean [khabāith]" Surah Al-A'raf (7): 157

Under Malaysian law the definition of 'halal' can be found in Order 3 (1) of the Trade Descriptions (Definition of Halal) Order 2011 which states; "When food or goods or services in relation to the food or goods used in the course of trade or business is described as "halal" or by any other expression indicating that Muslim are permitted to consume or use such food or goods or services means the food or goods or service in relation to the food or goods:

(a) neither is or consist of or contains any part or matter of an animal that a Muslim is prohibited by Hukum Syarak to consume or that has not been slaughtered in accordance with Hukum Syarak and fatwa

(b) does not contain anything impure according to Hukum Syarak and fatwa

(c) does not intoxicate according to Hukum Syarak and fatwa

(d) does not contain any parts of a human being or its yield which are not allowed by Hukum Syarak and fatwa

(e) is safe to be used or consumed, not poisonous or hazardous to the health

(f) has not been prepared, processed or manufactures using any instrument that was not free from anything impure according to Hukum Syarak and fatwa

(g) has not in the course of preparation, processing or storage been in contact with, mixed, or in close proximity to any food that fails to satisfy paragraph (a) and (b)."

The definition clearly represents the contemporary concept of halal which covers all types of goods and related services. However whether a particular product or service is halal requires a certification from an authorized body (Trade Descriptions (Certification and marking of Halal) Order 2011). In this regard halal has been described as a concept which involves specific standard, procedure and value that promotes cleanliness, safety, healthiness and reliability (Rezai, 2008). Nowadays halal has been recognized as a symbol of global quality assurance and thus becomes the choice of consumers of various places, races and religions. Apparently halal consumers are not confined to Muslims only. Due to high demand of halal products worldwide, halal symbol carries great commercial value and becomes a source of business opportunities. This has led to abuse of halal logo and false and misleading claims of halal by some unscrupulous traders to promote their business.

It should be understood that Muslim consumers consume not only for the sake of pleasure but also for performing their duties, responsibilities and mission as servants of Allah in this world (Sakr, 1993). Therefore, it is a religious duty of Muslims to eat good food and to avoid food that is forbidden as Allah says in Surah Al-Maidah: 87 \& 88;

"O ye who believe! Make not unlawful the good things which Allah Hath made lawful for you, and transgress not. Lo! for Allah loves not transgressors. Eat of the things which Allah hath provided for you lawful and good; but fear Allah, in whom ye believe!" 
It follows that Muslims are conscientious about the concept that "You are what you eat". It is a strong belief that food affects the personality and character of an individual (Ramli \& Amin, 2009). This belief is founded on several Quranic verses and the saying (Hadith) of the Holy Prophet Mohammed s.a.w. For example in Surah "Abasa: 14, Allah says; "Let the human reflect on the food he eats". In relation to the Hadith, Prophet Mohammad s.a.w was reported to have said;

"O ye, Sa'ad : improved your food, for your doa or prayers will be answered by Allah s.w.t. Any person who had eaten out of the haram food, for his 'ibadah will not be accepted for 40 days. The flesh which grows out of the haram once, will be burnt in Hell" (narrated by At Tabrani)

In another Hadith reported by Jabir r.a., the Prophet said;

"That flesh will not enter Paradise which has grown from Haram, and all flesh which has grown from Haram, the fire (of hell) is more worthy of it" (Narrated by Ahmed, Darimi, Baihaqi)

The hadith above clearly explain that the consumption of haram item is perceived to develop bad and unscrupulous behavior which will be the damaging factor for oneself and his family in this world and hereafter. Alcohol, for instance, has been proven to lead to addiction, misbehavior and negative impact on health (Hisham, 2012). Islam also teaches it's believers that to have a bright side of faith, an intellectual brain and a positive attitude they have to choose Halalan Toyibban food in their daily diet (Yumi et al., 2013). Halal food may also provide energy to the physical body and to the soul (Sabri, 2008).

The need for the Muslims to consume only halal products can also be understood from the very basic purpose of Shariah law which is aiming at preserving five essentials, namely, religion, human life, progeny, material wealth and the human faculty of reason (Sabik, 1986). The preservation of these essentials has been considered to be absolute requirements for the survival and spiritual wellbeing of individuals. (Munawar et al., 2012). The process of having or developing a good worldly life and hereafter depends on many factors and one of the major contributors is the intake and usage of good, healthy and quality food and other materials. Thus consuming and utilizing halal products is one of the ways to preserve the stated essentials.

In summary, consuming halal products is a reflection of strong faith, obedience to the command of the Creator and for the well-being and emotional and physical health of Muslims. Consequently any deceptive conduct or false and misleading representation with regard to halal products would definitely have serious consequences to Muslim consumers. Such acts cannot be tolerated and are strongly condemnable. It is the duty of the authority in charge of Muslims affairs to ensure the supply and availability of halal products for Muslim consumers. The authority is also under the obligation to cure the problem of false halal claims. In addition the victims of false halal products should also be accorded with the right to be compensated for the 'loss' or 'injury' caused by the product.

\section{Civil Liability for Supplying False Halal Products}

Halal products are just like other products in the context of sale of goods law. Therefore implied conditions under the Sale of Goods Act 1957 (SoGA) and implied guarantees under the Consumer Protection Act 1999 apply to the sale or supply of false halal products. Generally the sale of non halal product which was claimed to be halal either through labelling, representation or by other means indicating that the product is halal would have clearly breached the contractual terms between the supplier and the buyer. Liability may be imposed for breach of implied condition that the goods correspond with description under section 15 of the SoGA and section 34 of the CPA. As description generally refers to words which identify the type of goods supplied, the indication that it is halal good should be considered to be an important aspect of the description of the goods. This is supported by the finding of various studies that the majority of Muslims consumers in Malaysia will only buy products, especially food, with the halal logo (Ahmad, 2011; Ridzwan, 2007). It may also be argued that false halal product has failed to conform with the contract since it is not fit for halal consumers' purpose to consume halal products (section 14 of the SoGA and section 33 of the CPA).

In addition the CPA imposes on the supplier to supply goods which are acceptable in quality (section 32). Acceptable quality goods refers to goods which are fit for their general purpose, free from minor defects, acceptable in appearance and finish, safe and durable. These acceptable criteria need to be balanced with consumer expectation about the good after taking into consideration the nature of the goods, the price, any statements on the packaging or label or any representation made about the goods (section 32(2)). Based on the consumer expectation test, false halal goods are arguably not acceptable in quality since they not fit for purpose of consuming halal goods and not free from defect. Thus it can simply be concluded that the supply of false halal goods is not in conformity with the contract of sale and falls below the expectation of halal consumers. 
Nonetheless the main weakness of contractual liability is that it imposes liability on the sellers who, in most cases are not responsible for making false halal claims. Under the SoGA the seller may be protected by the doctrine of caveat emptor and exemption clause (section 14 and section 62) and the privity rule would confine the right to claim to the buyer. Although the liability for breach of guarantees under the CPA is wider as the protection extended to a mere user of goods and the liability may be imposed on the manufacturer, the remedies are confined to a repair, replacement and reduction in value of the good which arguably, are not so significant in cases of false halal product (Amin, 2007). Other kinds of loss or injury may be claimed as a consequential loss proven to be a result of the product's failure (section 41(2)). Whether mental distress or other emotional injury as a result of consuming non-halal goods can be claimed under this heading is highly debatable since 'a contract-breaker is not in general liable for any distress, frustration, anxiety, displeasure, vexation, tension or aggravation which his breach of contract may cause to the innocent party' (Bingham LJ in Watts v Morrow, 1993).

Similarly a claim for mere mental distress is not allowed under the law of negligence unless it leads to a positive psychiatric illness (McLoughlin v. O'Brian [1983] AC 410). A potential claim under the tort of negligence is further restricted by the requirements of the duty of care, breach of duty and remoteness of damage. Manufacturers may be said to owe a duty of care to produce halal products for Muslim consumers but they may escape liability by arguing that they have taken all reasonable steps to ensure compliance with halal requirements. Notably that the law of negligence is not relevant for cases of intentional act of halal certificate forgery or misuse of halal logo and other forms of false halal claims. It can be concluded that at this juncture that while the innocent supplier has a potential liability for breach of contract for selling false halal product, the liability of the manufacturer is limited in many respects.

\section{Liability under the Strict Liability Rule}

The principle of strict product liability can be found in Part X of the CPA which is the main statute on consumer protection in Malaysia. The CPA which came into force on the $15^{\text {th }}$ November 1999 aims to provide for the protection of consumers, the establishment of the National Consumer Advisory Council and the Tribunal for Consumer Claims. It basically covers all the main areas of consumer protection including supply of goods, supply of services, trade practices, unfair contract terms, product safety and liability and redress mechanism. The CPA has been influenced in one way or another by legal developments in the UK, Australia, New Zealand and Canada. The scheme of strict liability for defective product under Part X is based on Part 1 of the Consumer Protection Act 1987 of UK (Amin, 2007). Part X introduces a strict liability system in respect of death, personal injury and damage to property caused by a defect in the product. The primary liability is imposed on the producer, brand-owner and importer (section 68).

A producer is widely defined to cover every person involved in the manufacturing process, pre-manufacturing activity and the processing of a natural product such as food. In addition a producer of component parts and raw materials can be sued separately or jointly with the producer of final products. This is based on the definition of 'product' which includes 'a product which is comprised in another product, whether by virtue of being a component part or raw material or otherwise' (section 66(1)). Thus where a component of or raw material incorporated into a finished product is non-halal both the manufacturer of the component and the manufacturer of the finished product are potentially liable. The liability imposed is joint and several and the consumer therefore has the option of issuing proceedings as against multiple defendants along the supply chain. However the duty of the supplier under this Part is only secondary in the sense that he is liable only when he fails to inform the injured person, within a reasonable time, of the identity of the person who supplied him with the product. In the context of false halal products, the rule appears to be fairer to the supplier who is simply supplying other people products in ignorance of their halal status.

Obviously the main focus of the strict liability rule is the producer of product, who is the dominant link in the market chain. The producer is responsible not only for the production but also, through labelling and sales promotion activities, for creating consumer demand and expectations. The main purpose of the rule is to overcome the problems inherent in contractual and negligence remedies (The Law Commission, 1977). Thus the liability can be imposed without contractual relationship and without proof of fault or negligence. Unlike liability in negligence which is based on the conduct of the producer, the main focus of the strict liability rule is the defect in the product. The liability may be imposed by reason of the existence of a defect alone. For example, if a consumer is supplied with food contaminated with non-halal ingredient and it causes injury to him, the producer of the food will be strictly liable under Part X. The issue of how the food has became contaminated or whether a risk of contamination can be discovered or avoided is irrelevant. Furthermore a claim can be made by 'a person who suffered the damage', who is not necessarily the buyer (section 68(2)). The right to claim extends 
to mere users of the product and by-standers as long as they are able to establish the essential requirements of the rule, namely the damage or injury, the defect in the product and causal link between the injury and the defect.

\subsection{Is False Halal Product Defective?}

The common product defect is generally divided into three categories which are the design defect, manufacturing defect and marketing defect (Amin, 2007). The defects in the design is said to occur before the product is manufactured where the design is found to be inherently unsafe. It is a defect in a whole run of product which makes every item of that design to be defective in the same way. Meanwhile the manufacturing defect occurs during the process of production due to some abnormality in the process such as the inclusion of an unintended ingredient or the use of defective raw materials. Only a specific batch of product will be affected by this kind of defect. Finally the improper labeling, insufficient instructions or inadequate safety warnings is categorised as marketing defect. Technically, non halal products can fall under the ambit of 'defective product' under the category of manufacturing and marketing defect. Manufacturing defect occurs when the halal assurance system for the manufacturing of halal products is defective and unreliable. On the other hand, marketing defects may occur when the labeling of halal contradicts the content that the label presents. In both situations the product fails to fulfill the requirements of halalan thoyibban since it is no longer permissible, good, pure, clean, and wholesome.

However, defectiveness is the key concept of the strict liability rule and thus the product must be proved to be defective before liability can be imposed on the producer. Section 67(1) of the CPA states that 'there is a defect in a product for the purposes of this Part if the safety of the product is not such as a person is generally entitled to expect'. It is reasonably clear that the definition of 'defect' is based on the concept of safety. Section 67(4) states that safety in relation to a product shall include - (a) safety with respect to products comprised therein; (b) safety in the context of risk of damage to property; and (c) safety in the context of risk of death or personal injury. Thus a non-halal product can only be considered to be defective if it is unsafe in the sense it causes physical or property damage to the consumers. Mere cases of mislabeling or false labeling will not render the product to be defective if it causes no physical harm. This is obviously a major hurdle for the application of strict liability rule to the producer of false halal products unless a wider interpretation is given to the meaning of safety. From the Islamic point of view safety in relation to a product should include safety in the context of risk to five essentials that the Syariah aims to preserve. These include religion, progeny and intellect which are not covered under the existing law which is only concerned with physical safety to the body and property.

On the other hand Part $\mathrm{X}$ adopts the consumer expectation test in determining defectiveness. Safety is to be judged according to what 'a person is generally entitled to expect'. In the context of non-halal products, it may be argued that the Muslims at large are entitled to expect that the products supplied to them would be halal as claimed by the producer. Furthermore the issue of safety will be judged not based on actual expectation of the public but on their entitlement to expectation and this is the matter to be decided by the court. The CPA further sets out a list of circumstances which the judge may consider in deciding defectiveness. The relevant circumstances include the manner in which, and purposes for which, the product has been marketed and the use of any mark in relation to the product (section 67(2)). Obviously products which are marketed to Muslim consumers with the halal logo or other indication to that effect are very relevant factors in deciding their entitlement to expectation. This however does not answer the question whether Muslim consumers are entitled to expect that the product will be safe to consume in the sense that it carries no risk of causing not only physical damage but also spiritual and emotional injury.

\subsection{Recoverable Injury and Damage}

Another requirement of strict liability rule is the proof of injury. The injury must be proved to have been caused wholly or partly by the defect in the product (section 68). Based on the definition of 'damage' in section 66(1), Part X of CPA limits the aggrieved consumer to claim damages under three headings: death, personal injury, and damage to property including land. Nevertheless 'personal injury' is nowhere defined in the CPA as well the Civil Law Act 1956. Section 45(1) of the UK Consumer Protection Act 1987 defines personal injury to include 'any disease and any other impairment of a person's physical or mental conditions.' This would appear to bring nervous shock and other psychiatric illness within the ambit of the strict liability rule. In addition although damages for mental distress are not generally available for breach of warranty, especially in the context of a sale of goods contract as discussed above, there are authorities which support the possibility of recovery of damages for mental distress in product liability claims (Bernstein v. Pamson Motors (Golders Green) Ltd [1987] 2 All ER 220; Jackson v. Chrysler Acceptances Ltd. [1978] RTR 474.). A more comprehensive definition of damage in the context of product liability law can be found in the Liability for Damages Arising from Unsafe Product Act 
2009 of Thailand which defines damage to mean 'the damage arising from unsafe goods whether to life, body, health, mind or property excluding damage to the unsafe goods themselves' (section 4, B.E 2551). The section also provides definition of 'mental damage' which means 'pain, suffering, fear, worry, sadness, shame or other similar mental damage'.

Thus a Muslim consumer who suffered some kind of illness such as vomiting after consuming supposedly halal food clearly may have a claim under product liability law. However halal consumers rarely suffer physical injury after consuming non-halal product instead many of these victimized consumer complaint of experiencing emotional injury. This is clearly explained in the Islamic teachings that halal food may provide energy to the physical and the soul (Sabri, 2008; Qureshi et. al, 2012). In relation to this, faith has a very profound effect upon the spirit and body of a Muslim. There is relation or connection between the physical and spiritual strength of a person. The Muslim adherents would suffer severe emotional distress knowing that they have inserted or being inserted with non-halal goods into their body system. Their emotion is further disturbed by the fact that the effect of non-halal items may lie dormant over a long period of time which may also have spiritual and emotional implications to the future generations. Whether damage or injury can be extended to non-physical loss is highly debatable in the absence of clear definition of 'personal injury' in the Malaysian Act. It may be argued that since halal is so pertinent in Muslim life and part and partial of Muslim faith, deceptive consumption of non-halal products would cause severe emotional distress. Thus such a claim should be allowed by the court even in the absence of any detectable manifestation of physical injury. Such a claim can possibly be made under the UK law and can clearly be filed against producers of false halal products in Thailand.

But yet another hurdle to a successful claim under Part X is to establish a causal link between the defect in the product and adverse health, emotional or psychological effects suffered by the consumer. It may take some time before the consumers come to know about the real halal status of the product. In such a case, it is not possible to establish the immediate effect of consuming non-halal products. Nonetheless the requirement of causation may still be satisfied if it can be proven that the consumer suffers the injury after knowing the truthful fact about the product. However causation issues can be clouded by other factors such as intervening health factors.

\section{Conclusion}

A person who makes false or negligent claims that his product is halal where in actual fact it is not, should be held responsible for causing injury the consumers. The unexplored existing law in Malaysia provides a medium for the consumer of false halal products to claim remedies for breach of guarantees under the law of sale, damages under the law of negligence and strict liability as prescribed under the Consumer Protection Act 1999. Thus it exposes the manufacturer and supplier of false halal product to various civil liabilities which are yet to be tested in the court or the Tribunal for Consumer Claims. However it is reasonably clear that major hurdles for the application of strict liability for supplying non-halal products are to fulfill the requirements of defectiveness, damage or injury and the causation. Any non-halal product which is safe cannot be regarded as defective unless a wider interpretation is given to the meaning of safety to include spiritual and religious safety. Similarly a recoverable injury under Part X needs to be extended to mental injury if protection under the strict liability rule were to be afforded to the victim of non-halal products. Despite the restrictions and limitation, the producer of false halal product cannot simply set aside the idea of being sued by consumers. The potential exposure to a civil claim should provide a strong deterrent function equivalent to criminal sanctions and subsequently reduce the cases of halal deception.

\section{References}

Afifi, M., \& Alisa, A. (2014). Enforcement of Consumer Protection Laws on Halal products: Malaysian Experience. Asian Social Science, 10(3), 9-14. http://dx.doi.org/10.5539/ass.v10n3p9

Ahmad, N. L. (2011). Intention to Purchase Halal Products among Consumers (Unpublished master thesis). UUM.

Ali, A. Y. (2007). The Holy Quran: Text and Translation. Kuala Lumpur: Islamic Book Trust.

Amin, N. (1999). Product Liability under the Consumer Protection Act 1999. IIUM Law Journal, 7(2), 175-198.

Amin, N. (2007). Product Liability in Malaysia. Kuala Lumpur: Sweet \& Maxwell Asia.

Hashim, Y. Z. H. (2013). Halal Cosmetics: The Vogue. In Malaysia Halal: All That You Need to Know. Kuala Lumpur: Institut Terjemahan Negara (ITBM) and International Institute for Halal Research and Training (INHART))

Hashim, Y. Z. H. et al. (2013). Halal Diet a Bridge to Good Attitude. Halal Pages. 
Muhammad, N. M. N., Isa, F. M., \& Kifli, B. C. (2009). Positioning as Halal-Hub: Intergration Role of Supply Chain Strategy and Halal Assurance System. Asian Social Science, 5(7), 44-52. http://dx.doi.org/10.5539/ass.v5n7p44

Munawar, N. (2012, September 9-10). The Islamic Perspective Approach on Plant Pigments as Natural Food Colourants. Proceeding of the International Halal Conference (pp. 88-96). PWTC. http://dx.doi.org/10.1016/j.sbspro.2014.01.1120

Qaradawi, Y. al. (1962). The Lawful and the Prohibited in Islam (transalation). Kuala Lumpur: Islamic Book Trust.

Qureshi, S. S., Jamal, M., Qureshi, M. S., Rauf, M., Syed, B. H., Zulfiqar, M., \& Chand, N. (2012). A Review of Halal Food with Special Reference to Meat and its Trade Potential. The Journal of Animal and Plant Science, 22(2 Suppl), 79-83.

Ramli, N., \& Amin, N. (2007). Halal Food for Just and Equitable World: Malaysian Perspectives. Paper presented at $4^{\text {th }}$ ASLI Conference. Jakarta, 23-25 May 2007.

Rezai, G. (2008). Consumers' Confidence in Halal Labeled Manufacturing Food in Malaysia (Unpublished PhD Thesis). Universiti Putra Malaysia.

Ridzwan, N. et al. (2007). Halal Product from the Consumer Perception: An Oline Survey. Islamic Entrepreneurship Conference. KUIM.

Sabik, S. (1986). Fiqhus Sunnah. Indonesia: PD Hidayat.

Sabri, A. F. (2008). Wasiat Rasulullah s.a.w kepada Para Peniaga. Johor: Perniagaan Jahabersa.

The Law Commission and the Scottish Law Commission. (1977). Liability for Defective Products. HMSO Cmnd.

\section{Copyrights}

Copyright for this article is retained by the author(s), with first publication rights granted to the journal.

This is an open-access article distributed under the terms and conditions of the Creative Commons Attribution license (http://creativecommons.org/licenses/by/3.0/). 